\title{
MUUTUNUd ÕPIKÄSITUSE KEELELINE KONSTRUEERIMINE
}

\author{
Halliki Põlda, Katrin Aava
}

Ülevaade. Õppimise-õpetamise paradigmana on peavoolu tõusnud konstruktivism, mis - ehkki rikas eri teooriatest - näeb õppimist indiviidi teadmiste kogemusliku ülesehitamisena. Konstruktivistlikust õpikäsitusest lähtub ka Haridus- ja Teadusministeeriumi Eesti elukestva õppe strateegia 2020, milles keskse mõistena sõnastatud muutunud õpikäsitust nähakse õppija individuaalset ja sotsiaalset arengut toetavana, õpioskusi, loovust ja ettevõtlikkust arendavana. See tähendab ulatuslikku sisulist haridusuuendust, enamiku sotsiaalsete reformide takistajaks võib aga saada see, kuidas inimesed tegelikkuses toimuvaid muutusi kogevad. Ka Eesti haridusmaastiku tegeliku muutuse otsustab individuaalsete ja kollektiivsete tähenduste ühtimine ning ühtne rakendus hariduse argisituatsioonides. Niisugusel taustal kavandatud uuringu eesmärgiks on kirjeldada, kuidas muutunud õpikäsituse tähendust konstrueeritakse ja milliste diskursustega seda seostatakse.

Poolstruktureeritud fookusrühmaintervjuude alusel uuriti kriitilise diskursuseanalü̈̈s meetodil, kuidas konstrueerivad vana, osati siiani käibiva ning uue, muutunud õpikäsituse tähendusi Eesti hariduse sidusrühmad. Ühtlasi vaadati samal moel osalejate agentsust, mis annab vastuse, kas sidusrühmad kirjeldavad ennast muutustes osalejate ja neisse panustajana või on muutunud õpikäsituse jõustumine nende arusaamade kohaselt kellegi teise vastutus.

Eesti hariduse sidusrühmadena uuriti viit ametialaselt vastutavat fookusgruppi: õpetajakoolituse teadlastest õppejõud, hariduse tugiasutuste ametnikud, kohalike omavalitsuste haridusametnikud, koolijuhid ja õpetajad. Tulemusena selgus, et muutunud õpikäsituse tähendusist räägitakse ja neid toetatakse, kuid praktikas nimetatud põhimõtteid ei kasutata. Sidusrühmad näevad üksteist pigem takistuse kui koostööpartnerina.

Võtmesõnad: tekstilingvistika, kriitiline diskursuseanalüüs, muutunud õpikäsitus, sidusrühm, sotsiaalne innovatsioon 


\section{Uuringu eesmärk ja taust}

Eestis vastu võetud Eesti elukestva õppe strateegia 2020 oluliseks sisuks on muutunud õpikäsituse (MÕK) idee (vt allpool). See veel ei taga, et MÕK-ist kujuneb Eesti haridussüsteemis ja ühiskonnas sotsiaalne innovatsioon, mis avaldub nii osalevate indiviidide kui ka kollektiivsetes veendumustes ning kooli, klassi, kohaliku või riigi tasandi koostöös. Kuna haridusuuenduse kui sotsiopoliitilise protsessi lahendused luuakse sotsiaalsetes võrgustikes jagatud tähenduste kaudu, siis sõltub hariduse kõigi sidusrühmade arusaamadest, mida muutused tähendavad ja kas neis nähakse kasu. Ka kogumikus "Haridusfoorum 2012" rõhutatakse, et haridusstrateegia legitiimsus ei seisne vaid valitsuse ja riigikogu heakskiidus, otsustavaks saab eelkõige, kuidas huvipooled strateegia eesmärke mõistavad ja omaks võtavad. Just legitimatsiooniprotsessis ametiisikuna osalevate sotsiaalrühmade arusaamisi käesolevas alustavalt ja kvalitatiivselt uuritigi.

Järgnevas luuakse muutunud õpikäsituse teoreetiline raam ja esitatakse Eesti haridusuuenduste käik, et seejärel esile tuua uuringu valim ja metoodika.

\subsection{Muutunud õpikäsitus ja selle komponendid}

MÕK on Eesti elukestva õppe strateegia keskne mõiste, mille tähendus on toetada õppija individuaalset ja sotsiaalset arengut, õpioskusi, loovust ja ettevõtlikkust (2014: 4). Tuginetakse sotsiaalsele konstruktivismile, mille kohaselt õppimise käik ja tulemused lähtuvad õppija varasematest arusaamadest ja eelnevatest kogemustest (Mezirow 1990, Merriam, Caffarella 1999). Uut käsitust vastandatakse traditsioonilisele õpetajakesksele koolipraktikale, kirjeldades seda õpetajate ja õpilaste muutunud suhete kaudu, projekti- või probleemõppe, pööratud klassiruumi, uurimis- ja avastusõppe märksõnade kaudu. Muutust peavad toetama õpikeskkond, mis võimaldab paindlikumat aja- ja ruumikasutust, ja õppetöö korraldus, kus traditsiooniline õpetamine asendub õpetajate meeskonnatööga, toetades nii õppijate motivatsiooni kui ka õpetajate loomingulisust (Vinter jt 2015). Seega on haridusuuenduse võtmeküsimuseks koostöö.

Õpikäsituse rakendamist on mõõdetud OECD rahvusvahelise õpetamise ja õppimise uuringutes TALIS (2008, 2013). Uuendusliku õpikäsitusena kirjeldatakse seal õppeviise, mille puhul õppija aktiivsus on õppimisel keskne. Uuringutest selgub, et kuigi Eesti õpetajad on uuendusliku õpikäsituse pooldajad, kasutatakse klassis siiski valdavalt traditsioonilisi õppeviise (Loogma jt 2009, Loogma 2014). Teisalt on selgunud, et praktika mõistmise vastuolu ilmneb ka ülikoolis: tudengid tajuvad ülikoolis õpetamist ühesuunalise teadmiste edastamisena, õppejõud aga tajuvad, et teevad koostööd üliõpilaste arengu toetamiseks (Jõgi jt 2015). Seega ei ole MÕK ideena ühiskonnas rakendunud, vaid valitseb vastuolu teadmiste ja uskumuste ning käitumisviiside ehk teooria tundmise ja praktika vahel. 


\subsection{Sotsiaalse innovatsiooni ja muutunud õpikäsituse legitimatsiooni tegurid}

Võimalike uute õppekäsituste kasutuselevõttu on defineeritud hariduse sotsiaalse innovatsioonina (Fullan 2006: 28). Mitmed seda uurinud autorid toetuvad uusinstitutsioonide teooriale, kus sotsiaalseid institutsioone käsitletakse kui mistahes sotsiaalses süsteemis korra ja stabiilsuse tagajaid kolmel tasemel: 1) regulatiivne tase (seadusandlikud aktid); 2) normatiivne tase (sotsiaalsed normid); 3) kultuurilis-kognitiivne tase, mis hõlmab ühiseid, jagatud arusaamu ja mõtteviise, aga ka kultuuriliselt kujunenud, endastmõistetavaid mõtte- ja käitumismalle (Heiskala 2007, Loogma jt 2013). Haridusreformide läbikukkumisi kirjeldanud Seymour B. Sarason (1990) rõhutab mõtte-, tegutsemis- ja suhtlusviiside muutumise vajadust: otsustavaks saab, kas osatakse pidada tulemuslikke vestlusi või süüdistatakse probleemides teisi. Haridusuuendus tähendab sügavamaid ühiskondlike suhete muutumisi teadmusühiskonna kontekstis (Collinson, Fedoruk 2007). Seega ei piisa tegelike muutuste toimumiseks muutuse formaalsest seadustamisest, muutuma peaksid asjaosaliste käitumisnormid, mõtte- ja väljendusviis ning koostööoskused.

See, kuidas inimesed tegelikult muutust kogevad, on enamike sotsiaalsete reformide takistajaks. Uurijate (Elmore 1995, Fullan 2009) hinnangul head õppimis- ja õpetamisviisid ei levi ning paljud haridusreformid ebaõnnestuvad, kuna institutsionaliseeritud poliitilised ja majanduslikud suhted toetavad eelkõige õpikukeskset õppekava. Seega ei jõua haridusmuutused ellu uusliberaalse üleüldise mõju tõttu. Uuringutes (Hargreaves, Goodson 2006: 25-34) rõhutatakse, et 1970-ndatel PõhjaAmeerikas aset leidnud majanduslik õitseng ja rahvastiku juurdekasv soodustas ühiskonnas õpetajate toetatud haridusuuendusi, mis keskendusid õppijakesksele õppele; 1990-ndatest toimunud majanduslik õitseng ja kultuuriline üleilmastumine tõi kaasa rahvusvaheliste äriorganisatsioonide survel testimise ja standardiseerimise, mille tagajärjel on vähenenud õpetaja autonoomia, kitsenenud õppekava ning arusaam õpetajast kui sotsiaalse missiooni kandjast.

\subsection{Eesti situatsioon ja uuringu tähtsus selle kontekstis}

Eesti taasiseseisvusaja haridusmuutustes on samuti kirjeldatud kahte lainet: esmalt viisid ühise tähendusvälja laienemise tõttu läbiräägitud arusaamad õpetuse sisu muutumiseni; 1990-ndatel Eesti haridusellu jõudnud uusliberalistlike põhimõtete mõjul kujunes koolide konkurents koos gümnaasiumi riigieksamite tulemuste avalikustamisega peamiseks süsteemi tõhusust tagavaks jõuks (Loogma jt 2013). Kirjeldatud haridusmudelit on nimetatud üleilmseks haridusreformiks (Sahlberg 2008). Nii on uusliberaalsete maade muutused hariduses kujunenud osalejate igapäevaelu praktikateks, mis jagavad võimu ümber, aga ei oma kõigi osalejate jaoks jõustavat toimet (Loogma jt 2012).

Siinse uuringu keskmes on küsimused, milliste diskursustega seostatakse muutunud õpikäsitust ja kas need kattuvad ametlikus diskursuses loodud tunnustega, millised on variatsioonid sidusrühmade arusaamades ning kuidas sidusrühmad suhtuvad muutuse jõustumisse. Tulemusena kirjeldatakse, kuidas haridussüsteemi olulised sidusrühmad kogevad uut õpikäsitust ja selle jõustumist, täpsemalt: kes ja 
milliste diskursuste kaudu seda kirjeldab ja milliseid keelekonstruktsioone seejuures kasutatakse ning kes on sidusrühmade silmis muutuse eest vastutajad.

\section{Meetod ja valim}

Tulenevalt uuritavast valdkonnast ja püstitatud eesmärgist lähtutakse uuringus fenomenograafiast, mida üks suunale alusepanijatest - Ference Marton - mõtestab kui instrumenti kirjeldamaks inimeste mõtlemise erinevaid viise. Võimalik on kirjeldada, kuidas inimesed kogevad, tajuvad ja mõistavad neid ümbritseva maailma erinevaid aspekte ja maailmas eksisteerivaid nähtusi (Marton 1986: 31). 1970-ndatel kasutusele võetud haridusuuringute strateegia on hoolimata 1990-ndatel levinud kriitikalainest (vt Reed 2006) siiani sobilik meetod nähtuse kogemise viiside väljaselgitamiseks (Marton, Booth 1997). Nii toetubki siinne uuring fenomenograafia ideele selgitamaks, kuidas kogevad ja mõtestavad Eesti hariduse sidusrühmad - sidusrühmateooria (Freeman 2010) kohaselt inimesed või grupid, kes otseselt mõjutavad haridusstrateegia elluviimist ja/või on selle elluviimisest mõjutatud - MÕK-i ümbritsevas sotsiokultuurilises kontekstis.

Poolstruktureeritud fookusgrupi intervjuu andmekogumismeetodina on olemuselt reflektiivne ja tundlik selle suhtes, kuidas inimene uuritavat nähtust käsitleb (Barnard jt 1999, Kvale 2008). Litereeritud materjali eritlemiseks kasutatakse kvalitatiivse sisuanalüüsi ja kriitilise diskursuseanalüüsi (ingl critical discourse analysis, CDA) kombinatsiooni. Sisuanalüüsil eristatakse ja grupeeritakse sarnased vastused ja käsitlused ning moodustatakse sidusrühmadepõhised tulemuskategooriad, mis kirjeldavad tähenduste sarnasusi ja erinevusi ning väljendavad kvalitatiivselt erinevaid nähtuste kirjeldamise, analüüsimise ning mõistmise viise (vt Barnard jt 1999). Kategooriate kirjeldamiseks ja teksti varjatud tähenduste otsimiseks on kasutusel CDA kui meetod, mis võimaldab esile tuua tekstides keeleliste valikute kaudu väljendunud ühiskondlikud kokkulepped ning tähendused. Diskursust käsitletakse sotsiaalse praktikana, kommunikatsiooniviisina teatud sotsiaalses, kultuurilises, ajaloolises, poliitilises situatsioonis (Dijk 2005: 3). CDA üks olulisemaid autoreid Norman Fairclough $(1992,1993,1999)$ on tegelenud sotsiolingvistilise uurimusega, uurides teksti sõnavara, grammatikat, semantikat.

Selgitamaks, kuidas MÕK-i kontekstis konstrueeritakse osalejad ja vastutajad, uuritakse, kuidas väljendatakse agentsust. Tegevused eeldavad tegijana varjatud või tagaplaanil olevaid inimesi ehk agente (Leeuwen 1996). Lausesemantilist analüüsi tehes vaadeldakse, millal kajastab lause tegevust või tegu, mis on agentsed, ning millal protsessi või juhtumit, mis on automaatsed. Agentiivsus tähendab EKG II (1993: 24) järgi agendi ehk situatsiooni suhtes aktiivse, seda kontrolliva osalise olemasolu. Aktiivlausetes esineb tegevussubjekt grammatilise subjektina, passiivlausetes selline vastavus puudub. Subjektita konstruktsiooni käsitlemine passiivi alaliigina rajaneb eeldusel, et tegumoe vahetus põhineb eelkõige püüdel vältida mingitel kaalutlustel tegija esiletõstmist (samas: 30). Agentiivsuse uurimine võimaldab kirjeldada, kelle vastutusena nähakse ühiskonnas MÕK-i jõustumist ning millise rolli ja vastutuse osalejad ise võtavad, keda nimetatakse arengu takistajana.

Fairclough (2005) on uurinud haridusdiskursuste muutusi ja selle keelelisi väljundeid. Uusliberaalse ideoloogia mõju haridusdiskursusele on kirjeldanud veel 
mitmed autorid (Spring 2004, Field 2006, Fejes 2008), täpsemalt CDA meetodit kasutades Luke (1996), Stack (2006, 2007), Manteaw (2008), Aava (2011). Uuritud on, kuidas uut haridusdiskursust haridusdokumentides ja meediatekstides konstrueeritakse, vähem on kasutatud intervjueerimist (Moreau jt 2007). Seni pole uuritud, kuidas hariduse eri sidusrühmad konstrueerivad haridusuuenduste tähendusi ja enese vastutust uuenduste agendina.

Valimi moodustavad haridussüsteemi sidusrühmadest moodustatud viis fookusgruppi, kelle koostöö soodustab MÕK-i kasutuselevõttu. Esimesse fookusgruppi kuuluvad õpetajakoolituse teadlastest õppejõud, kes koolitavad õpetajaks õppijaid; teise hariduse tugiteenuseid pakkuvad SA Innove arenduskeskuste õppenõustamis- ja karjääriteenuste spetsialistid; kolmandasse kohalike omavalitsuste haridusametnikud, kelle ülesannete hulka kuulub haridusseaduse järgi metoodiline teenindamine ja ka haridusjuhtide ning pedagoogide nõustamine koolikorralduslikes küsimustes (RT); neljandasse koolijuhid ja viiendasse õpetajad (nii alushariduskui ka koolipedagoogid). Grupid koosnesid viiest inimesest ja olid moodustatud ühisel põhimõttel: igas grupis oli inimene, kes oli seotud uue haridusstrateegia elluviimiseks kokkukutsutud ümarlauaga ja kes kutsus intervjuule oma kolleegid. Nii osales neid, kes olid kursis uue õpikäsitusega, kui ka neid, kes sellega tuttavad polnud. Eraldi ei kutsutud kokku lastevanemate fookusgruppi, kuna nemad nimetatud ümarlauda ei kuulunud. Lapsevanemad, kui hariduse oluline sidusrühm, olid siiski olemasolevates fookusgruppides esindatud: mitmed eri gruppide liikmed võtsid aeg-ajalt sõna just lapsevanema positsioonilt ja uuringu seisukohalt oli see olulise tähtsusega ning leidis rakendamist.

Intervjuud toimusid ajavahemikul 14.4.2015-12.6.2015, nende pikkus varieerus 70 minutist 95 minutini. Intervjuud salvestati diktofoniga ja litereeriti, intervjuukava lähtus püstitatud eesmärgist, sisaldades küsimusi:

1) Mida tähendab teie jaoks muutunud õpikäsitus ja milles seisnevad need muutused?

2) Millised on teie hinnangul peamised takistused muutunud õpikäsituse rakendumiseks?

3) Mis soodustaks muutunud õpikäsituse rakendumist?

4) Milline on teie enda valmisolek muutunud õpikäsituse kasutuselevõtuks?

Moderaatoritena töötasid intervjuudel kaks uurijat, kelle ülesanne oli hoida diskussiooni fookust, innustada grupi liikmete vaba eneseväljendust ja julgustada grupi liikmeid esitama ka vastuolulisi seisukohti (vt Kvale 2008: 74). Kokkuvõttes eristusid intervjuude käigus diskursused, mille kaudu osalejad kirjeldasid, kuidas nad MÕK-i tähendust mõistavad, millised on selle rakendumist soodustavad ja takistavad asjaolud ning kuidas nad enda ja teiste sidusrühmade rolli ja vastutust selles protsessis näevad.

\section{Tulemused}

Tulemused esitatakse sidusrühmade kaupa intervjueerimise järjekorras, tuues kohe välja nii ühised aspektid kui ka arusaamade variatiivsuse: esmalt MÕK-i tähendus, siis takistused, soodustavad asjaolud ning viimasena on vaatluse all, kuidas vastajad 
kirjeldasid enda valmisolekut. Iga küsimuse all on eraldi koondatud esinenud diskursused koos intervjuunäidetega.

\section{1. Õpetajakoolituse teadlastest õppejõud (FG1)}

Õppejõud kirjeldasid muutunud õpikäsitust õpetaja ja õpilase suhete, vastutuse ning hindamise diskursuse kaudu. Haridussuhteid kirjeldas sidusrühm kontrolli ära andmise metafoori kaudu.

- $\quad$ Kõik need toredad kujundavad ja muud hindamised - kui me ei anna vastutust ja kontrolli käest ära, sïs nad ei rakendu.

- See suhete muutumine tähendab just seda, et õpetaja ei ole midagi ülimuslikku, et tekib pigem partnerlussuhe ja võib tekkida ka vastupidine efekt, et õpetaja õpib õpilaselt.

Kui suhtediskursuses esines nii muutumisele kui ka mittemuutumisele viitavaid näiteid, siis vana õpikeskkonda kirjeldati muutumatu õpikeskkonna (aja- ja ruumikasutuse) diskursustega.

- 45 min suudavad kõik õppijad täpselt ühte moodi, ühes tempos asja omandada... Seal võivadki inimesed liikuda erinevas tempos, me ei saa neid sundida ühes ajas ja ruumis tegema asju täpselt ühte moodi.

- Selline klassikaline pingiridadesse jaotatud näoga õpetaja poole suunatud klassiruum teenib distsipliini eesmärki, aga mitte kuidagi moodi ei soodusta koostööd teise kuklasse vaatamine.

Intervjuudes põhjendati seisukohti teaduslike argumentidega, tauniti neid, kes uusi meetodeid ei rakenda (teevad tunnist tunnini, peaks koolist minema peksma).

- Ma ei saa kuidagi nõus olla sellega, kuiöeldakse, et uus ei ole rakendunud. Meil on olemas ju uuringud, mis kõnelevad erinevatest õpetajarühmadest. On need, kelle käes see on rakendunud, kes on ta ise loonud enne veel, kui see kuskil kirja pandi, ja teised, kelle käes ta ei hakkagi tööle, sellepärast, et nad teevad oma [tööd] tunnist tunnini. No ja sïs on veel kolmandad, kes on täielik riskirühm, kelle peaks koolist minema peksma.

Samas rääkisid õppejõud MÕK-ist õpetaja usaldamise ja autonoomsuse kontekstis, rõhutades õpetaja oskusi ja pädevust.

- Esimene asi, mida me peaksime tegema, on see, et õpetaja saaks asju ise otsustada, et õpetajat usaldataks ja selleks tuleb ära lõpetada see õpetajate igasugune totaalne kontrollimine või see, et sa pead kogu aeg iga asja pärast aru andma kellelegi, et sa pead oma tegevuskavad tegema pikaajaliselt ette, et keegi need kinnitabja ütleb, kas su tegevuskava sobib või mitte.

Intervjuudest ilmnes, et MÕK-i jõustumist takistavad õppejõudude hinnangul õpetajad, lapsevanemad ja kooli hindamissüsteem.

- Õpetaja on konservatiuv - tema õpetab nii, nagu teda on õpetatud. 
- Neid mehhanisme praegu paraku kooli juhtkonnal ei ole, et saada suhteliselt kergesti lahti professionaalselt ebasobivast inimesest [õpetajatest].

- Kui laps läheb koju, ema-isa küsivad, et mis hinde sa said? Mis mõttes ei saanud hinnet?

Soodustava asjaoluna eendusid õpetajakoolituse õppejõudude fookusgrupis regulatsioonivajaduse, õpetajakoolituse ja vastutusala jagunemise diskursused.

- Niikaua kui need asjad ei ole paika pandud riiklikul tasandil, siis sellest on vähe kasu, kui igaüks omamoodi tegutseb ja seda tôlgendab.

- $\quad$ See mõte, et kui me oleme sïn praegu ülikoolis õpetajakoolitajad, et muutused peavad ka siin toimuma, kuidas me koolitame õpetajaid. Kui me neid muutusi ellu ei vii või seda mudelit ei paku, kuidas nad [üliõpilased] saaksid selle kogemuse siin kätte.

Oma valmisolekut MÕK-i põhimõtete järgi tegutseda hindasid õppejõud positiivselt, kirjeldades seda oma ideede eest võitlemise diskursuse kaudu.

- $\quad$ Ma arvan, et ma olen olnud üks, kes on saanud meedias ka piitsa selle pärast, etjulged natukene mingeid radikaalsemaid seisukohti välja öelda.

Samas tunnistati, et erinevate takistuste tõttu (õpiviisid, -keskkond) on neid põhimõtteid ülikoolis keeruline rakendada - ilmnes teooria ja praktika vastuolu.

- Õpetame väitlema. Selleks on vaja aega, et väidelda, see võtab tohutu aja. No rühmatööd. Lõpmatu palju rühmatöid ja siis nad ütlevad, õpetaja, aga meil loenguid ei olnudki ju, muudkui rühmatöö.

- Ma ei oska neid passiivseid ikkagi aktiivseks muuta, ma ei oska neid asju rakendada ja siis ma lähen kohati seda rada, et ok, ma sïs pean selle loengu.

- $\quad$ Siis kui sulle pannakse 70 inimest loengusse, antakse auditoorium, kus pingiread on paigas [L2: pingid põrandas kinni veel] ja tehnika ei tööta, siis ma olen täiesti võimetu, ma olen jõuetu. .. Kui me nïmoodi edasi läheme, sïs me jääme selle klassikalise loengu juurde ja need inimesed, kes siit lähevad, nad ei ole näinud, kuidas uus õpikäsitus toimib ja nad võtavad ju ikkagi need mudelid ju üle.

Seega õpetajakoolituse õppejõud ei näe ennast MÕK-i elluviijatena, aktiivlausetes nimetavad tegevustena ajalehes väljaütlemist, tunnistavad ebaõnnestumist: ma olen võimetu, olen jõuetu. Vastajad nimetavad takistusi, kõnelevad ei-sõnumitega (ei ole aega), kasutades umbisikulist tegumoodi (antakse auditoorium). Ka selles olukorras, kui vastaja näeb enda sidusrühma rolli protsessi mõjutajana, kasutatakse tingivat kõneviisi (peaksime oskama paindlikult vastavalt olukorrale reageerida). Samuti nähakse vastutajana riiki (pole paika pandud riiklikul tasandil). 


\subsection{Hariduse tugiteenuste ametnikud (FG2)}

Tugiteenuste ametnikud väljendasid MÕK-i õpilase-õpetaja muutunud suhtediskursust nii realiseerumise kaudu kui ka tingivalt. Aktiivses rollis esines vastajate sõnastuses nii õppija kui ka kool.

- Õpilane on rohkem keskmes, ta on natuke aktiivsemas rollis ka, ta ei ole selline, et istub ja on passiivne ja kuulab.

- Kool peaks soodustama seda, et meil on ennastjuhtivad inimesed.

Samuti ilmnes õpikeskkonna diskursuses, et muutusi kohati ei toimu.

- Ma lisaks süa kooli füüsilise keskkonna, et mul on üks sõbranna algklasside õpetaja ja ta on väga hädas sellega, et lauad ja toolid ongi n-ö üksteise taga klassides.

MÕK-i seostati ka hindamise diskursusega, näidates kohatisi probleeme ja muutumatut praktikat. Märkimisväärsena toodi esile, et saavutuste asemel mõõdetakse tänases koolis vigu.

- On olemas mingisugune kujundav hindamine, millest me ei tea päris täpselt, meil on olemas välishindamine.

- $\quad$ Me mõõdame vigu.

Vastajad kirjeldasid mitmel korral olukorda mitte niivõrd haridusametniku, kuivõrd lapsevanema vaatepunktist, seda nii positiivses kui ka negatiivses võtmes.

- $\quad$ Ma ise olen kõrvalt jälgides näinud, kuidas õpetajad teevad koostööd.

- Mina näen seda oma lastega, et lapsed ei taha koolis käia, ja ma ei saa aru, et kui algklasside lapsed räägivad tegelikult, et ma ei taha.

Samas nähti ennast informeeritumana kui õpetajaid, nimetades asjatundliku agendina Innovet.

- Kust need õpetajad tegelikult peaksid teadma uuenenud õpikäsitusest? Meie sïn räägime, Innove enamjaolt teab.

MÕK-i kasutuselevõtu takistajana nimetati kolme olulist tegurit: ajapuudust, kooli juhtkonda ja lapsevanemaid, esile tõusis ka vastutuse jagamise diskursus.

- Näiteks kooli juhtkond ei toeta koostöövorme, pole aega teha koostööd.

- Kui lapsevanemad ei tea, et võiks ka natukene nõuda tänapäeval teisi asju seal koolis.

MÕK-i kasutuselevõttu soodustaks tugiasutuste fookusgrupi hinnangul protsessiosaliste koostöö, pingeridade kadumine ja õpetajahariduse muutumine.

- Soodustab see, kui tervikuna vaadatakse need asjad üle. Umbes nii, et ühe laua taha vaadatakse erinevad takistused ja siis antakse neile terviklahendused, et kaoksid ära need vastuolud alates kooli pingeridadest.

- $\quad$ Mis ülikoolis sïs on, et kuidas seal peaks siis neid aineid andma? Kas seal lähme vana viisi edasi või? 
Fookusgrupi liikmete valmisolekut MÕK-i põhimõtete järgi tegutseda väljendati vastuoluliselt õpetaja, lapsevanema ja ametniku rollist. Õpetaja vaatepunktist tajuti võimetust MÕ K-i järgi tegutsemiseks, lapsevanemana taheti muuta õpetajat, ametnikuna oldi valmis, taheti panna õpetajaid mõtlema.

- No kui mina peaks täna kooli õpetama minema, sïs ma selgelt olen valmis ja ainult seda teeksingi, aga ei tea, kui seal sein vastas on või keegi mind ei toeta selles osas, äkki käib see entusiasm maha. Aga lapsevanemana ma jälgin hoolega ja olen ka õpetajale arenguvestluses märku andnud, kui ma näen, et midagi on sellist, mida õpetaja saaks muuta oma senises tegevuses.

- $\quad$ Mingisugused kokkulepped peaksid ühiskonnas muutuma, et õpetajad lepivad kokku, et need on nüüd need, millest me kinni peame kõik koos.

- Kuna meie ametikoht võimaldab siseneda kooli ning neil teemadel rääkida, siis me teeme seda väga innustunult, mina olen viimased aastad seda ideed kandnud ennastsalgavalt.

Hariduse tugiteenuste töötajad väljendavad aktiivlausetes ennast neil teemadel ametniku rollis koolides rääkijana, õpetajate mõtlemapanijatena, sõnastades enda valmisolekut; lapsevanema rollis on nad jälgijad, õpetajatele märku andjad. Väljendatakse ka passiivlausete kaudu: asjad peaksid ühiskonnas muutuma, vastaja kasutab tingivat kõneviisi: kui mina peaks täna kooli ópetama minema. Kuigi rõhutatakse kõigi koostööd, siis agentidena nimetatakse lausetes eelkõige õpetajaid (õpetajad lepivad kokku, muudavad seniseid tegevusi).

\subsection{Kohalike omavalitsuste haridusametnikud (FG3)}

Kohalike omavalitsuste haridusametnikud kirjeldasid MÕK-i õpetaja ja õpilase suhete kaudu, esile toodi õpetaja-õpilase rollide vahetumist, agentidena esinesid õpetajad ja juhid/direktorid. Oluliseks kujunesid vastutuse jagamise ja (kujundava) hindamise diskursus.

- Õppimine peab olema lõbus, õppimine peab olema protsess, kus tegelikult õpitakse, mitte nüvõrd ei õpetata, sest et oma loomult tänane õpikäsitus, kus õpilased õpivad pingis ja kuulavad, mida õpetaja tarka neile ütleb, ja siis tehakse kontrolltöid ehk testitakse pidevalt õpilasi, on, selge see, vananenud õpikäsitus.

- ..nõuab ka õpetajalt asuda õppija rolli.

- ..kujundav hindamine, mis tekitab tohutult poleemikat.

MÕK-i rakendumise takistusi nimetasid enim just kohalike omavalitsuste esindajad. Peamiste takistustena nähti õpetajaid, lapsevanemaid, vanameelseid direktoreid, koostöö puudumist, riigieksamite süsteemi, koolidevahelist võistlust, hirmu eksimise ees. Esile kerkis ka selgitustöö diskursus.

- ..et õpetajad on tegelikult väga konservatiive seltskond. 
- Mina arvan, et peaks lapsevanematele seletama rohkem lahti, mida see muutunud õpikäsitus tähendab.

- Ja kui ikka direktoril ei ole soovi ega tahtmist muutustega tegeleda..

- Takistus on kõige suurem, kui koostööringis kedagi ei ole: kas omanik, direktor, õpetajad, lapsevanemad, kui keegi sellest puudub.

- ..tegelikult rïgieksamite tulemustes oleme 2oondad, et senimaani olime 2ondad, ehk hirm tegelikult midagi kihva keerata.

Soodustavate teguritena märgiti ära direktorite mõjuvõimu, piisavat selgitustööd ja olulisena toodi välja e-õppe osakaal ning kasv õppeprotsessis.

- Et kui on hea direktor, siis ta suudab tegelikult ka väikeses kogukonnas, ta tihti ju kuulub volikokku või võib valitsusele väga lähedal olla või päris konfliktis seda niikuinii ei tehta, selgitada sealsamas vallajuhtidele ja kogukonnale.

- Gümnaasiumiastmes on mitmetesse koolidesse tulnud see e-õpe.

- Mina arvan, et peaks lapsevanematele seletama rohkem lahti, mida see muutunud õpikäsitus tähendab. Ja ma arvan, et suurem osa õpetajaid ei ole selles väga osavad.

Haridusametnike fookusgrupi liikmed väljendasid valmisolekut ise MÕK-i põhimõtete järgi tegutseda, nähes ennast veenjate, informeerijate ja kõneisikutena.

- Mulle tundub, et eile veensin isegi ühe lapsevanema ümber.

- Juhtide informeerimise, juhtidele info andmise, kommunikeerimisega sellega kõik tegelevad.

Osalejad kasutavad aktiivlauseid suhtlemise kontekstis: veensin lapsevanema ümber, ma räägin kaasa. Enda rolli näevad kohalike omavalitsuste haridusametnikud informeerimises ja kommunikeerimises.

\subsection{Direktorid (FG4)}

Direktorid kirjeldasid uut õpikäsitust õppijakesksena õpetaja ja õpilase muutunud suhte kaudu, rõhutades hariduse eri osapoolte koostööd.

- Kui 25-3o aastat tagasi oli fookuses tervikühiskond, sïs praegu on fookuses õpilane-üksikisikja see erisus paistab väga tugevalt silma. Õpilane on kõige tähtsam, kõik toetavad õpilast.

Rõhutati suhete muutust lastevanematega ning esile toodi koostöö olulisus.

- Igas protsessis on lapsevanem ja nad on väga targaks saanud, nad teavad õppekavast palju, nad oskavad sekkuda, küsida väga tarku küsimusi. Nad on võrdne partner teatud tasandil õpetajaga, juhtkonnaga.

- Väga tähtis on meeskonnatöö ja tegelikult me toome küll välja indiviidi, aga koolimeeskonna töö, rühmatööd, koostöö vanematega, üldsusega. 
Väga oluline roll direktorite vestluses oli hariduslike erivajaduste diskursusel, mida kirjeldati kui tehislikult loodud takistust õppetööle. See diskursus on vastuolus eelpool nimetatud õppijakeskse kõik toetavad õpilast diskursusega.

- $\quad$ Me ainult diagnoosime ja sildistame, teeme raviplaane, justkui 21. sajandi õpilane oleks tõesti mingisugune defektne, keda peab kogu aeg lappima ja parandama.

- $\quad$ Kui on raske HEV õpilane klassis, siis paratamatult ühel või teisel moel kannatavad kõik teised.

Direktorid ei nimetanud ühtegi MÕK-i soodustavat tegurit, vaid keskendusid takistustele, milleks olid nii õpetajakoolitus kui ka riigi ja ühiskonna toetuse puudumine.

- Selle õpetajakoolitusega on ka miskit mäda, et neid õpetajaid tegelikult ei tule. Midagi peab muutma õpetajakoolitusega, rïk peab tootma õpetajaid.

- $\quad$ Õpetajad on need, kes on nõrgad, aga ühiskond seda sellisel kujul ei näe. Öeldakse, et peate hakkama saamaja koolijuht - teie läbi oma kodukorra lahendage ja viige asjad ellu. Seadusandlus ei toeta seda.

- Miks õpetajat ei väärtustata? Meil on õpetaja nagu kõige madalam töötegija.

Valmisolek ise MÕK-i põhimõtete järgi tegutseda väljendus direktoritel õpetajate ja tegevuste toetamises (panna tähele ja tunnustada õpetajaid, õppekäigud ja ainetevahelised projektide päevad).

Koolijuhid sõnastavad enda rolli õpetaja tähelepanijatena, tunnustajatena. Keeleliselt aktiivlausetes nimetavad ennast: kasutatakse meie-vormi (me oleme sõber). Vastutajana nimetatakse riiki (riik peab tootma õpetajaid). Õpetajate tootmise väljendiga tekib vastuolu konstruktivismi põhiseisukoha, õppimise individuaalse tähendusega.

\section{5. Õpetajad (FG5)}

Õpetajad kirjeldasid MÕK-i õpetaja-õpilase muutunud suhte, aktiivõppe meetodite ja kujundava hindamise diskursuse kaudu. Muutunud suhtest räägiti õpilaskesksuse diskursuse kaudu, kus keeleliselt on aktiivses rollis ikka õpetaja (õpetaja lähtub).

- Kui seni lähtuti ainest, materjalist, süs täna ta [õpetaja] lähtub rohkem ópilasest ja tehaksegi tööd selle nimel, et õpilane tahaks.

Muutust kirjeldati mitmel korral lapsevanema rollist vaadates õppetöö korralduse muutumise ning kujundava hindamise ja vastutuse jagamise diskursuse kaudu.

- Kui ma lapsevanemana jälgin, sïs mul on tunne, et ma näen seda, et ühelt pooltjah, on tekkinud selliseid aktiivõppe päevi, konkreetselt nimetatudki aktiivõppe päevadeks .. lapsevanemana saan ma hästi vastuolulist infot.

- $\quad$ Mina olen vaadanud, et teine laps, kes mul kuuenda lõpetas ja kui tema vaatab selle kolmanda [klassi] lapse asju, siis ta kohe tunnetab, et need on hoopis teistmoodi kui olid kolm aastat tagasi. 
- Kool, kus mina tööl olin, hindas küll vanal hindelisel moel, aga kool, kus üks laps käib, on kujundav hindamine ja minu meelest see on küll 180 kraadi fookuse muutmine õppimisele. Nagu vastutuse jagamise koht. Et mitte kool või õpetaja või lapsevanem ei vastuta nahaja karvadega, vaid tegelikult vastutab õppija.

Ilmnes ka näide õpetajakesksest diskursusest: üks õpetaja kirjeldas õpetajat kui agenti, kelle roll on õpilasi eluks ette valmistada, ning ta polnud nõus MÕK-i defineerima.

- On muutunud nii palju tõepoolest kui see keskkond ja kuna põhimõtteliselt iga õpetaja ikkagi tahab oma õpilasi ette valmistada millekski, mis tuleb pärast kooli - olgu see süs eksam või elu, ükskõik. Kui te palute mul defineerida muutunud õpikäsitust, siis no ei.

Takistusi kirjeldati hirmu, ajapuuduse, puuduliku õpetajakoolituse, ülekoormuse ja õpiku õpetamise diskursuste kaudu.

- $\quad$ Mis õpetajatel puudub, on õpetajate ühine aeg.

- Teine asi, mis seoses sellega tekib, on hirmud, et kas ma teen õigesti.

- $\quad$ Noor õpetaja, kes on tulnud sellest mudelist, kus teda on õpetatud nï koolis kui ka ülikoolis selle vana mõtlemise või ülevalt alla stïlis, sïs ta kannab seda edasi.

- $\quad$ Noh, me alustasime 20 tunniga nädalas, aga elu läks ikka nii, et mõne kuu pärast andsime 27 tundi nädalas. Midagi uut ma genereerida praktiliselt ei jõua.

- Ja siis kui ma läksin kooli, siis ma avastasin, et ma hakkasin nagu õpikut oppetama..

MÕK-i soodustaks õpetajate hinnangul juhtkond, kogemus, koostöö, haridusinstitutsioonide ja ühiskonna toetus.

- . .kuidas koolijuhtkond selle enda jaoks mõtestab.

- $\quad$ Soodustab, kui nï õpetaja kui õppija saavad selle protsessi käigus teistsuguse kogemuse.

- $\quad$ Ma ütlen hästi lakooniliselt: ühtne hoiak, usaldus ja usk.

- $\quad$ Panen ühte lausesse mitu: head näited, avalik arutelu, positïvne surve, kaasa arvatud välishindamine ja kvalifikatsiooninõuded, teaduspõhised tõendused, levinud metoodika ja õppematerjalide pank, järelkasv.

Kui vastajad arutlesid valmisoleku üle ise muutunud õpikäsituse põhimõtete järgi tegutseda, siis räägiti vaheldumisi nii õpetaja kui ka lapsevanema rollist, tunnistati vastuolusid.

- Lapsevanemana toetan ma seda täiega, õpetajana täpselt sama moodi.

- Majulgen väita, et paljudes õpetajates kindlasti on see valmisolek olemas, täna on lihtsalt puudu sellest julgusest ja ajast. .. Ja paraku kindlasti kõige suurem mure ôpetaja jaoks on tegelikult lapsevanem. 
- Lapsevanema takerdun tõsiselt lõksudesse.

Õpetajad agendina lausetes toetavad, omavad valmisolekut, kuid aktiivselt tegevustes ei kasuta. Üks õpetaja väljendab end tegutsejana: ma teen hästi palju.

\section{Järeldused ja arutelu}

Muutunud õpikäsituse mõistet seostavad sidusrühmad õpetaja ja õpilase muutunud suhtega; oluline rõhk on paindlikul õpikeskkonnal, isegi kui see ei ole realiseerunud. Samuti seostatakse mõistet õppetöö korraldusega, kus n-ö traditsiooniline õpetamine peaks asenduma õpetajate meeskonnatööga. Seega ühtivad sidusrühmade arusaamad sõltumata kirjeldatud praktikast muutunud õpikäsitust avavas kirjanduses esitatud diskursustega (Vinter jt 2015) ja haridusstrateegias sõnastatud arusaamadega, kus kirjeldatakse muutuse toimumist keskkonna ja õppetöö korralduse kaudu.

Sidusrühmade arusaamade variatiivsus tõusis esile vastuoluliste diskursuste kaudu. Õppejõud nägid probleemi vanameelses õpetajas (õpetaja on konservatiiv tema õpetab nii, nagu teda on õpetatud), tunnistades samal ajal, et ei kasuta ka ise uusi meetodeid (ma ei oska neid passïvseid ikkagi aktiivseks muuta). Hariduse tugiteenuste ametnikud rääkisid MÕK-ist koostöö diskursuse võtmes, ennast nähti valgustajana (et seda viia õpetajateni või nad kasvõi selleks hetkeks mõtlema panna, et kas nad saaksid midagi teha teisiti, kui nad täna teevad).

Koolijuhid kirjeldasid muutunud õpikäsitust paljuski hariduslike erivajaduste diskursuse kui takistuse diskursusena, sattudes vastuollu esmalt enda nimetatud õppijakesksuse põhimõttega (kui on raske HEV õpilane klassis, siis paratamatult ühel või teisel moel kannatavad kõik teised). Vastuolulised on õpetaja tunnustamise (Miks õpetajat ei tunnustata?) ja majandusretoorikat kasutav tootmisdiskursus (Riik peab tootma õpetajaid).

Kohalike omavalitsuste haridusametnike sõnastuses olid fookuses kujundava hindamise, lastevanemate harimise ja koolidirektori diskursused. Õpetajate fookusgrupis esines vastuolulisi diskursusi: õppijakeskne diskursus (tööd tehaksegi selle nimel, et õpilane tahaks) esines kõrvuti õpetajakesksega (iga õpetaja ikkagi tahab oma õpilasi ette valmistada millekski). Vastuolu tekkis ka seal, kus vastajad kirjeldasid MÕK-i põhimõtteid enda töö kontekstis: õpetajana toetan, aga lapsevanemana takerdun (FG1); ametnikuna toetan, aga õpetajana ebaõnnestuksin (FG2).

Haridusuuenduste uurijad (Sarason 1990, Collinson, Fedoruk 2007 jt) on rõhutanud reformide õnnestumist soodustavatena mõtte-, tegutsemis- ja suhtlusviiside muutuste vajadust ning koostöö olulisust. Peaaegu kõik sidusrühmad pidasid koostööd oluliseks (jagatud vastutuse diskursus), ent teisi sidusrühmi nähti pigem takistava kui soodustavana (vrd Eesti elukestva... 2014). Õpetajakoolituse õppejõud nimetasid takistusena õpetajaid, koolijuhte ja lapsevanemaid; tugiteenuste esindajad koolijuhte ja lapsevanemaid, samuti õpetajakoolitust; kohalike omavalitsuste haridusametnikud nimetasid takistusena õpetajaid ja lapsevanemaid; direktorid õpetajakoolitust; ka õpetajad ise rõhutasid probleeme õpetajakoolituses. Samas kurdavad ülikoolide õppejõud umbisikulist tegumoodi kasutades, et õpetajat ei usaldata, ning koolijuhid muretsevad selle pärast, et õpetajat ei väärtustata. Nii on õpetaja usaldamise ja autonoomia diskursus vastuolus. Hindamise ning koolide võrdlemise 
diskursust nimetavad vastajad enim haridusuuendust takistavana. Kohalike omavalitsuste haridusametnikud tõid muutunud õpikäsituse jõustumist soodustava faktorina esile direktoreid, õpetajad nimetasid kooli uuendusmeelset juhtkonda.

Kui kõnelejad sõnastavad lauseid viisil, kus nad on agendid, siis kasutatakse verbe tean, toetan, räägin. Intervjuudes esineb palju põhjendusi, miks MÕK-i põhimõtteid ei saa kasutada: aeg ja ruum ei võimalda (selleks on vaja aega, et väidelda), keskkond ei toeta (pannakse 70 inimest loengusse, antakse auditoorium, kus pingiread on paigas), lastevanemate toetuse puudumine ja õppijate vastuseis (mis mõttes ei saanud hinnet?). Samuti nimetasid sidusrühmad agendina abstraktset kooli või riiki: kool peaks soodustama seda, et tervikuna vaadatakse asjad üle (FG2), riik ei soodusta (FG4), riik peab tootma õpetajaid (FG4).

Nii toetab siinse uuringu tulemus TALIS $(2008,2013)$ uuringute tulemusi, mille kohaselt õpetajad teavad ja toetavad uut lähenemist, aga ise ei kasuta (Loogma jt 2009, Loogma 2014). Samuti toetavad tulemused Jõgi jt (2015) uuringut, mille kohaselt valitseb ülikoolis vastuolu teadmiste ja uskumuste ning tegelike käitumispraktikate vahel.

Selleks, et rakenduks sotsiaalne innovatsioon ja võetaks kasutusele uued õpetamisstrateegiad, peaksid muutuma nii mõtte- kui ka käitumismallid, individuaalsed ja kollektiivsed tähendused peaksid ühtima ning inimesed peaksid neid ka kasutama (Fullan 2006, 2007, 2008, Loogma 2013). Uuringu põhjal võib väita, et muutunud õpikäsitust mõistetakse sarnaselt: tähendused pigem ühtivad nii erialakirjanduses kui ka strateegiadokumentides sõnastatuga. Samas esineb mitmeid vastuolusid ning tekib vastasseis, kui osalejad mõtestavad MÕK-i tähendusi enda töö kontekstis. Vastajate keelekasutuses ilmneb, et uutest muutunud õpikäsituse tähendustest küll räägitakse, seda toetatakse, kuid praktikas neid põhimõtteid ei kasutata; koostöö vajadust mõistetakse, kuid üksteist nähakse takistuse, mitte ressursina.

\section{Viidatud kirjandus}

Aava, Katrin 2011. Teadmuspõhise ühiskonna ja elukestva õppe diskursuste rekontekstualiseerimine Eestis. - Eesti Rakenduslingvistika Ühingu aastaraamat, 7, 5-18. http:// dx.doi.org/10.5128/ERYa7.01

Barnard, Alan; McCosker, Heather; Gerber, Rod 1999. Phenomenography: A qualitative research approach for exploring understanding in health care. - Qualitative Health Research, 9 (2), 212-226. http://dx.doi.org/10.1177/104973299129121794

Collinson, Vivien; Fedoruk, Tanya Cook 2007. Organizational Learning. Improving Learning, Teaching, and Leading in School Systems. Sage Publication.

Dijk, Teun A. van 2005. Ideoloogia. Multidistsiplinaarne käsitlus. Tlk. Merit Karise. Tartu: Tartu Ülikooli Kirjastus.

Eesti elukestva õppe strateegia 2020. Tallinn, 2014. https://www.hm.ee/sites/default/files/ strateegia2020.pdf (3.3.2016).

Eesti Haridusfoorum 2012. Miks haridusmuutused visalt ellu jõuavad? 26. ja 27. aprill 2012, Tallinn. Ettekannete ja artiklite kogumik. Tallinn: Eesti Haridusfoorum, 2012.

EKG II = Erelt, Mati; Kasik, Reet; Metslang, Helle; Rajandi, Henno; Ross, Kristiina; Saari, Henn; Tael, Kaja; Vare, Silvi 1993. Eesti keele grammatika III. Süntaks. Eesti Teaduste Akadeemia Keele ja Kirjanduse Instituut. Tallinn

Elmore, Richard 1995. Getting to scale with good education practices. - Harvard Educational Review, 66 (1), 1-26. http://dx.doi.org/10.17763/haer.66.1.g73266758j348t33

Fairclough, Norman 1992. Discourse and Social Change. Cambridge: Polity Press. 
Fairclough, Norman 1993. Critical discourse analysis and the marketization of public discourse: The universities. - Discourse and Society, 4 (2), 136-168. http://dx.doi.org/ 10.1177/0957926593004002002

Fairclough, Norman 1999. Global capitalism and critical awareness of language. - Language Awareness, 8 (2), 7-83. http://dx.doi.org/10.1080/09658419908667119

Fairclough, Norman 2005. Critical discourse analysis in trans-disciplinary research on social change: Transition, re-scaling, poverty and social inclusion. - Lodz Paper in Pragmatics, 1, 37-58.

Fairclough, Norman; Wodak, Ruth 1997. Critical discourse analysis. - Teun van Dijk (Ed.), Discourse as Social Interaction. London: Sage, 258-284.

Fejes, Andreas 2008. Historicizing the lifelong learner. Governmentality and neoliberal rule. - Andreas Fejes, Katherine Nicoll (Eds.), Foucault and Lifelong Learning. London: Routledge, 87-99.

Field, John 2006. Lifelong Learning and the New Educational Order. London: Trentham Books.

Freeman, Edward 2010. Strategic Management: A Stakeholder Approach. USA: Cambridge University Press. http://dx.doi.org/10.1017/CBO9781139192675

Fullan, Michael 2006. The New Meaning of Educational Change. 4th ed. New York: Teachers College Press.

Fullan, Michael 2009. Large-scale reforms comes of age. - Journal of Educational Change, 10 (2), 101-113. http://dx.doi.org/10.1007/s10833-009-9108-z

Hargreaves, Andy; Goodson, Ivor 2006. Educational change over time? The sustainability and non-sustainability of three decades of secondary school change and continuity. - Educational Administration Quarterly, 42 (1), 3-41. http://dx.doi. org/10.1177/0013161X05277975

Heiskala, Risto 2007. Social innovations: Structural and power perspectives. - Timo J. Hämäläinen, Risto Heiskala (Eds.), Social Innovations, Institutional Change and Economic Performance. Cheltenham: Edward Elgar, 52-79.

Jõgi, Larissa; Karu, Katrin; Kravi, Kristiina 2015. Rethinking teaching and teaching practice at university. - International Rewiew of Education, 61 (1), 61-77. http://dx.doi. org/10.1007/s11159-015-9467-Z

Kvale, Steinar 2008. Doing Interviews. London: Sage.

Leeuwen, Teun van 1996. The representation of social actors. - Carmen Rosa CaldasCoulthard, Malcolm Coulthard (Eds.), Texts and Practices: Readings in Critical Discourse Analysis. London: Routledge, 32-70.

Loogma, Krista 2014. Õpetajate praktika ja klassikeskkond. - Ülle Übius, Kairit Kall, Krista Loogma, Meril Ümarik, Rahvusvaheline vaade õpetamisele ja õppimisele. OECD rahvusvahelise õpetamise ja õppimise uuringu TALIS 2013 tulemused, 112-133.

Loogma, Krista; Ruus, Viive-Riina; Talts, Leida; Poom-Valickis, Katrin 2009. Õpetaja professionaalsus ning tõhusama õpetamis- ja õppimiskeskkonna loomine. OECD rahvusvahelise õpetamise ja õppimise uuringu TALIS tulemused.

Loogma, Krista; Tafel-Viia, Külliki; Ümarik, Meril 2012. Social Innovation: Three Approaches. ZSI Discussion Paper, Nr 24. Innovating Innovation by Research - 100 years after Schumpeter.

Loogma, Krista; Tafel-Viia, Külliki; Ümarik, Meril 2013. Conceptualising educational changes: A social innovation approach. - Journal of Educational Change, 14 (3), 283-301. http://dx.doi.org/10.1007/s10833-012-9205-2

Luke, Allan 1996. Text and discourse in education: An introduction to critical discourse analysis. - Review of Research in Education, 21 (1), 3-48.

Manteaw, Bob Offei 2008. When businesses go to school: Neoliberalism and education for sustainable development. - Journal of Education for Sustainable Development, 2 (2), 119-126. http://dx.doi.org/10.1177/097340820800200209 
Marton, Ference 1986. Phenomenography - A research approach to investigating different understandings of reality. - Journal of Thought, 21, 28-49.

Marton, Ference; Booth, Shirley 1997. Learning and Awareness. New Jersey: Lawrence Erlbaum Associates.

Merriam, Sharan B.; Caffarella, Rosemary S. 1999. Learning in Adulthood. San Fransisco: Jossey-Bass.

Mezirow, Jack 1990. How critical reflection triggers transfomative learning. - J. Mezirow (Ed.), Fostering Critical Reflection in Adulthood. San Fransisco: Jossey-Bass.

Moreau, Marie-Pierre; Osgood, Jane; Halsall, Anna 2007. Making sense of the glass ceiling in schools: An exploration of women teachers' discourses. - Gender and Education, 19 (2), 237-253. http://dx.doi.org/10.1080/09540250601166092

Reed, Brandon I. 2006. Phenomenography as a way to research the understandings by students of technical concepts. - Technological Innovation and Sustainability. Sao Paulo, Brazil, 1-11.

RT = Eesti Vabariigi haridusseadus. https://www.riigiteataja.ee/akt/30588.

Sahlberg, Pasi 2008. Rethinking accountability in a knowledge society. - Journal of Educational Change, 11 (1), 45-61. http://dx.doi.org/10.1007/s10833-008-9098-2

Sarason, Seymor Bernard 1990. The Predictable Failure of Educational Reforms. San Fransico: Jossey-Bass.

Spring, Joel 2004. How Educational Ideologies are Shaping Global Society: Intergovernmental Organizations, NGOs, and the Decline of the Nation State. New Jersey: Lawrence.

Stack, Michelle 2006. Testing, testing, read all about it: Canadian press coverage of the PISA results. - Canadian Journal of Education, 9 (1), 49-69. http://dx.doi. org/10.2307/20054146

Stack, Micelle 2007. Representing school success and failure: Media coverage of international tests. - Policy Futures in Education, 5 (1), 100-110. http://dx.doi.org/10.2304/ pfie.2007.5.1.100

Vinter, Kristi; Slabina, Pille; Heidmets, Mati 2015. Õpikäsitus ja koolikultuur. - Õpetajate Leht, 6.2.

Halliki Põlda (Tallinna Ülikooli humanitaarteaduste instituut) uurimishuvideks on kvalitatiivanalüüsi metoodika, mõistete ja fenomenide analüüsi ja interpreteerimise võimalused avalikus kommunikatsioonis.

Narva mnt 25, 10120 Tallinn, Estonia

halliki.polda@tlu.ee

Katrin Aava (Tallinna Ülikooli humanitaarteaduste instituut) peamised uurimisvaldkonnad on meediatekstide, haridustekstide kriitiline diskursuseanalüüs.

Narva mnt 25, 10120 Tallinn, Estonia

aava@tlu.ee 


\section{LINGUISTIC CONSTRUCTION OF A CHANGED LEARNING APPROACH}

Halliki Põlda, Katrin Aava

Tallinn University

According to the Estonian Lifelong Learning Strategy 2020 of the Ministry of Education and Research, a changed learning approach is an approach supporting the individual and social development, learning skills, creativity and enterprisingness of a learner. The aim of the study is to describe which discourses are associated with the changed learning approach and whether they coincide with the indicators created in the official discourse. Also, the aim is to determine, based on language use, how the stakeholders themselves relate to the education innovation.

Five focus groups were studied as stakeholders: teacher training faculty researchers, officials from education support bodies, education officials from local governments, school headmasters and teachers. The data collected from the interviews with focus groups were analysed by using the critical discourse analysis method.

As the result, it appeared that the changed learning approach is connected with discourses formulated in educational documents and professional literature (discourse of the changed teacher-student relationship, changed learning environment discourse etc.), however, the descriptions of the stakeholders often do not refer to these changes. Almost all stakeholders formulated the need for cooperation but did not so much list the other stakeholders as a contributing factor. Therefore, it appeared that stakeholders saw other stakeholders more as preventive factors. The results of the study indicated that there are several contradictions between the descriptions of changed learning approach and an opposition is created where the participants handle the meanings of changed learning approach in the context of their own work. The new meanings of the changed learning approach are discussed but not used in practice.

Keywords: text linguistics, critical discourse analysis, changed learning approach, stakeholder, social innovation 